\title{
Identification of calpain cleavage sites in the G1 cyclin- dependent kinase inhibitor p19iNK4d
}

\author{
Joma Joy,a, Narasimharao Nalabothula1,a, \\ Madhumita Ghosh', Oliver Popp², Marianne \\ Jochum², Werner Machleidt $^{3}$, Shirley Gil- \\ Parrado $^{2, b}$ and Tad A. Holak ${ }^{1, *}$ \\ ${ }^{1}$ Max-Planck-Institut für Biochemie, D-82152 \\ Martinsried, Germany \\ ${ }^{2}$ Abteilung für Klinische Chemie und Klinische \\ Biochemie, Chirurgische Klinik Innenstadt, Klinikum der \\ Ludwig-Maximilians-Universität München, D-80336 \\ München, Germany \\ ${ }^{3}$ Adolf-Butenandt-Institut der Ludwig-Maximilians- \\ Universität München, D-80336 München, Germany \\ * Corresponding author \\ e-mail: holak@biochem.mpg.de
}

\begin{abstract}
Calpains are a large family of $\mathrm{Ca}^{2+}$-dependent cysteine proteases that are ubiquitously distributed across most cell types and vertebrate species. Calpains play a role in cell differentiation, apoptosis, cytoskeletal remodeling, signal transduction and the cell cycle. The cell cycle proteins cyclin D1 and p21 $1^{\mathrm{KIP} 1}$, for example, have been shown to be affected by calpains. However, the rules that govern calpain cleavage specificity are poorly understood. We report here studies on the pattern of $\mu$-calpain proteolysis of the p19ink4d protein, a cyclin-dependent kinase $4 / 6$ inhibitor that negatively regulates the mammalian cell cycle. Our data show new characteristics of calpain action: $\mu$-calpain cleaves p191NK4d immediately after the first and second ankyrin repeats that are structurally less stable compared to the other repeats. This is in contrast to features observed so far in the specificity of calpains for their substrates. These results imply that calpain may be involved in the cell cycle by regulating the cell cycle regulatory protein turnover through CDK inhibitors and cyclins.
\end{abstract}

Keywords: calpain; calpastatin; cyclin-dependent kinases; nuclear magnetic resonance spectroscopy; proteolysis; p19ink4d.

\section{Introduction}

Calpains are a family of non-lysosomal, cysteine proteinases that show $\mathrm{Ca}^{2+}$ dependent papain-like cysteine protease activity (Goll et al., 2003). The two ubiquitously expressed calpain forms, with proteolytic activities requiring $\mu \mathrm{M}$ and $\mathrm{mm}$ calcium, were identified and named

\footnotetext{
a These authors contributed equally to this work.

b Present address: Novartis Pharma AG, Werk Klybeck, CH-4002 Basel, Switzerland.
}

as $\mu$ and $\mathrm{m}$ (also referred to as I and II) calpains, respectively (Mellgren, 1980; Dayton et al., 1981; Goll et al., 2003). Calpains are heterodimeric proteins, composed of a large $80-\mathrm{kDa}$ catalytic subunit organized in four domains (I-IV) and a common, small, 30-kDa regulatory subunit organized in two domains (V and VI). Domain II is a cysteine protease domain and contains the catalytic cysteine, histidine and asparagine residues. Domain IV is a $\mathrm{Ca}^{2+}$-binding domain in which five EF-hand motifs are present. The small regulatory subunit is composed of an N-terminal glycine-clustering hydrophobic region (domain V) and a C-terminal $\mathrm{Ca}^{2+}$-binding domain (domain $\mathrm{VI}$ ). The hydrophobicity of the $\mathrm{N}$-terminal domain (domain V) has been taken as an indication of its role in membrane anchoring (Kuboki et al., 1987, 1990; Inomata et al., 1989, 1990; Lee et al., 1990; Molinari et al., 1994; Moldoveanu et al., 2002, 2003; Khorchid and Ikura, 2002; Pal et al., 2003). Calpains have potential biological functions in apoptosis, the pathology of degenerative diseases, and mediating intracellular calcium signals (Nicotera et al., 1986; Du et al., 1995; Spencer et al., 1995; Arora et al., 1996; Huang and Wang, 2001; Glading et al., 2002). A number of studies indicated that calpains have a role in the cell cycle, specifically in the $G_{1}$ to $S$ transition (reviewed in Goll et al., 2003). For example, rapid loss of cyclin D levels in serum-starved NIH 3T3 cells is restored by synthetic calpain inhibitors or by overexpression of an endogenous inhibitor of calpain, calpastatin (Choi et al., 1997). Calpain-mediated degradation of $\mathrm{p} 21^{\mathrm{KIP} 1}$, which is a member of CIP1/KIP1 family of CDKIs, has been reported in preadipocyte cell cycle progression and differentiation (Patel and Lane, 2000). However, the biological role of calpain in cell cycle regulation is still poorly understood.

Although the rules that govern calpain specificity have not yet been determined, experimental reports published so far indicate that proteolysis by calpains is limited and does not lead to small peptides, suggesting that calpains may modulate the functions of substrate proteins by cutting their interdomain regions (Croall and Demartino, 1991). In this study, we attempted to characterize calpain-preferred cleavage positions in p19ink4d. p19ink4d is a 165 -aa protein that comprises $10 \alpha$-helices assembled sequentially in five ankyrin repeats and it shares structural and biochemical properties of the other three INK4 family proteins, p16 ${ }^{\mathrm{INK} 4 \mathrm{a}}, \mathrm{p} 15^{\mathrm{INK} 4 \mathrm{~b}}$ and $\mathrm{p} 18^{\mathrm{INK} 4 \mathrm{C}}$ (Baumgartner et al., 1998; Sherr and Roberts, 1999). The four INK4 family proteins negatively regulate the mammalian cell cycle by specifically binding and inhibiting CDK4/CDK6, which are involved in phosphorylation of the retinoblastoma tumor suppressor protein and thereby in $\mathrm{G}_{1}$-S control (Morgan, 1995; Harper and Elledge, 1996; Pines, 1996; Bartek et al., 1997). CDK inhibitors have also been implicated in terminal differentiation and senescence (Bartek et al., 1997; Serrano et al., 1997; Ruas and 

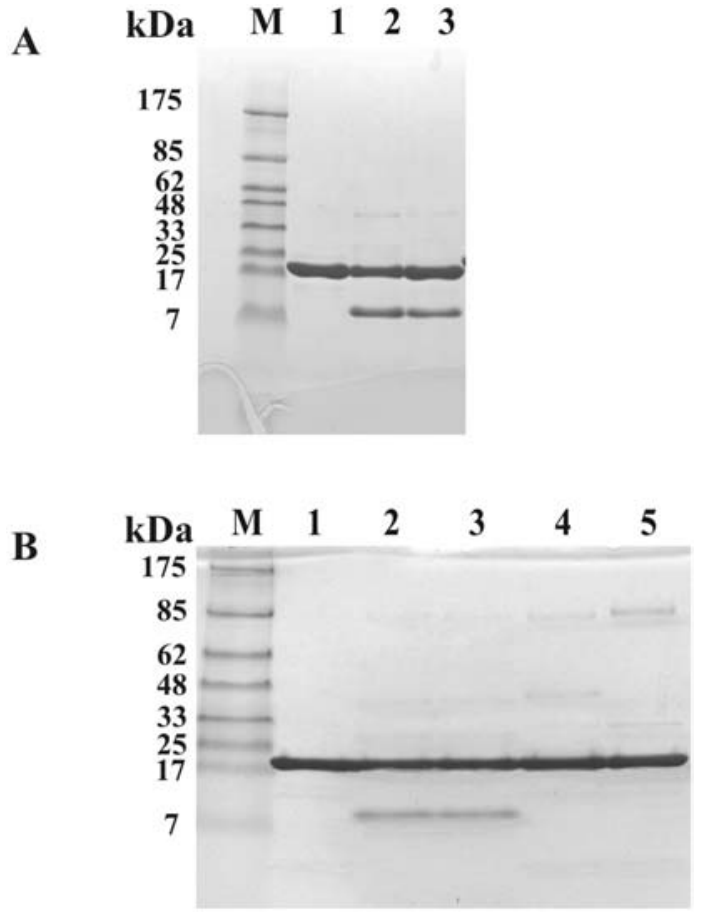

Figure 1 SDS-PAGE analysis of fragments generated by calpain cleavage.

(A) $\mu$-Calpain-mediated proteolysis of $\mathrm{p} 19$. Lane $\mathrm{M}$, prestained molecular mass protein marker; lane 1, p19 incubated in the calpain assay buffer; lane 2, p19 digested with calpain in the presence of $\mathrm{Ca}^{2+}$ at a molar ratio of 50:1; lane 3, p19 digested with calpain in the presence of $\mathrm{Ca}^{2+}$ at a molar ratio of 100:1. (B) Calpastatin inhibitory and $\mathrm{Ca}^{2+}$-dependent protease assay. Lane M, prestained molecular mass protein marker; lane 1, p19 incubated in the calpain assay buffer; lanes 2 and 3 show p19 digested with calpain in the absence of calpastatin and presence of 1 and $5 \mathrm{mM} \mathrm{Ca}^{2+}$, respectively; lanes 4 and 5 show p19 digested with calpain in the absence of calpastatin and $\mathrm{Ca}^{2+}$, and in the presence of calpastatin and $\mathrm{Ca}^{2+}$.

Peters, 1998; Sherr and Roberts, 1999). p16 inactivation by mutations is one of the frequent defects contributing to tumorigenesis (Bartek et al., 1997; Serrano, 1997; Ruas and Peters, 1998; Sherr and Roberts, 1999). Inactivation of p19 through mutations contributes to bladder cancer (Tsutsumi et al., 1998) and spermatogenesis defects in mice (Zindy et al., 2001). We have chosen to study $\mathrm{p} 19$ as a model protein because the structure of this protein is known and, in contrast to the calpain substrate proteins studied so far, it is not composed of globular domains linked by large solvent-exposed flexible fragments.

\section{Results}

\section{Calpain-mediated proteolysis of p19 and calpastatin inhibitory actions}

Calpain is an autolytic enzyme. Experiments by Tompa and Friedrich (2000) and Li et al. (2004) have shown that calpain autolyses within the first $30 \mathrm{~min}$, which results in protease activation. Our previous studies on calpain

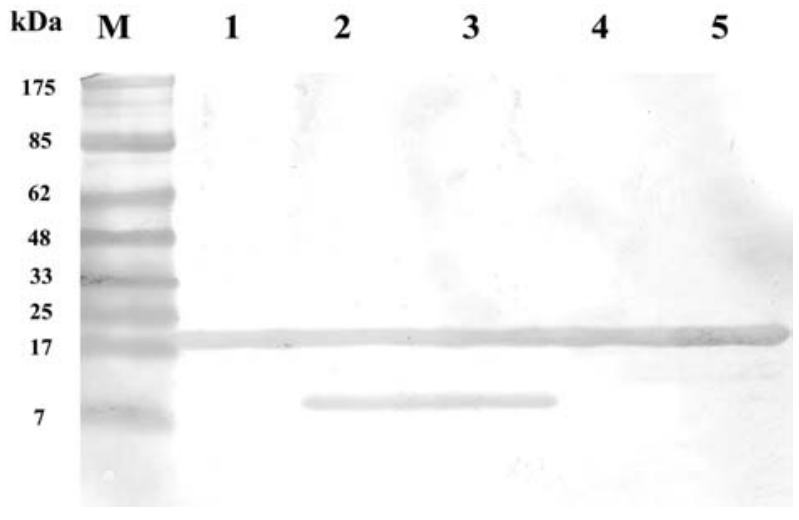

Figure 2 Western blot of $p 19$ fragments generated by $\mu$-calpain protease cleavage.

p19 was digested with calpain in the presence or absence of calcium and calpastatin, resolved by SDS-PAGE and transferred onto nitrocellulose membranes. Non-cleaved and cleaved fragments of $\mathrm{p} 19$ were detected by immunoassaying with $\mathrm{p} 19$ polyclonal antibodies. Loading of lanes was as for Figure 1B.

action on IGFBPs (insulin-like growth factor binding proteins) showed the same cleavage pattern, for 1,2 and even $4 \mathrm{~h}$ (Ghosh et al., 2005). This suggested that an increased time interval would not result in any extra cleavage sites. On the basis of this, we carried out our experiments on calpain-mediated proteolysis of p19ink4d and performed all our experiments for $1 \mathrm{~h}$. p19ink4d was recombinantly expressed and purified (Figure 1A, lane 1). SDS-PAGE analysis of the in vitro assay carried out by incubating p19 with $\mu$-calpain in the presence of $\mathrm{Ca}^{2+}$ resulted in $\mathrm{p} 19$ fragmentation. The reaction results were not dependent on protein concentration, because an equal amount of $\mathrm{p} 19$ was cleaved in the presence of $\mathrm{Ca}^{2+}$ at molar ratios of 50:1 and 100:1 (Figure 1A, lanes 2 and $3)$. The protein was not cleaved in the calpain assay buffer in the absence of $\mu$-calpain (Figure 1B, lane 1), which acted as a control for the experiment. No fragmentation of p19ink4d was observed in the presence of the endogenous calpain inhibitor, calpastatin, and calcium (Figure 1B, lane 5), or in the absence of calcium and calpastatin (Figure 1B, lane 4). Hence, calpastatin efficiently blocked the cleavage of p19ink4d, as no cleavage fragments of the protein were observed. In addition, no cleavage was observed in the absence of calcium, which is in agreement with the fact that calcium is necessary to induce the autocatalytic activity of calpain. On the other hand, an almost equal amount of $\mathrm{p} 19$ was cleaved by $\mu$-calpain in the presence of $5 \mathrm{~mm} \mathrm{CaCl}{ }_{2}$ (Figure 1B, lane 3) compared to $1 \mathrm{mM} \mathrm{CaCl}_{2}$ (Figure 1B, lane 2).

\section{Analysis of cleaved p19ink4d products by Western blotting}

To further assay the products after $\mu$-calpain digestion, Western blot analysis was carried on the p19ink4d cleavage products. The digested products were resolved by SDS-PAGE and transferred onto a nitrocellulose membrane and were further detected by 19 polyclonal antibodies, as shown in Figure 2. 
A

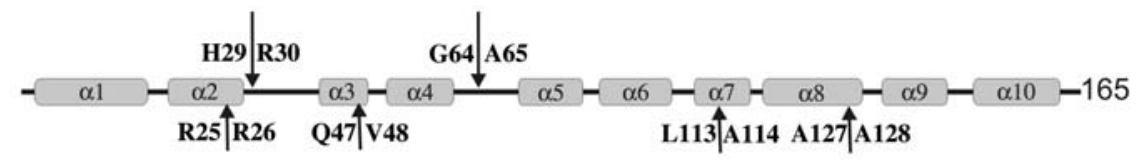

$-\alpha 1-\alpha 2$.
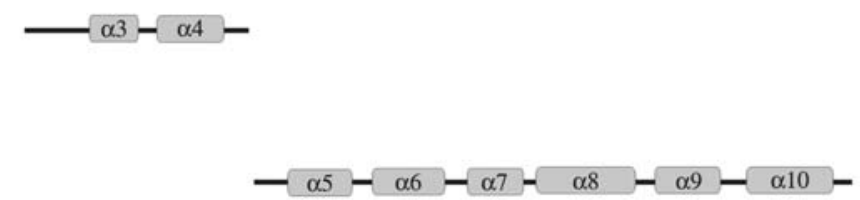

B

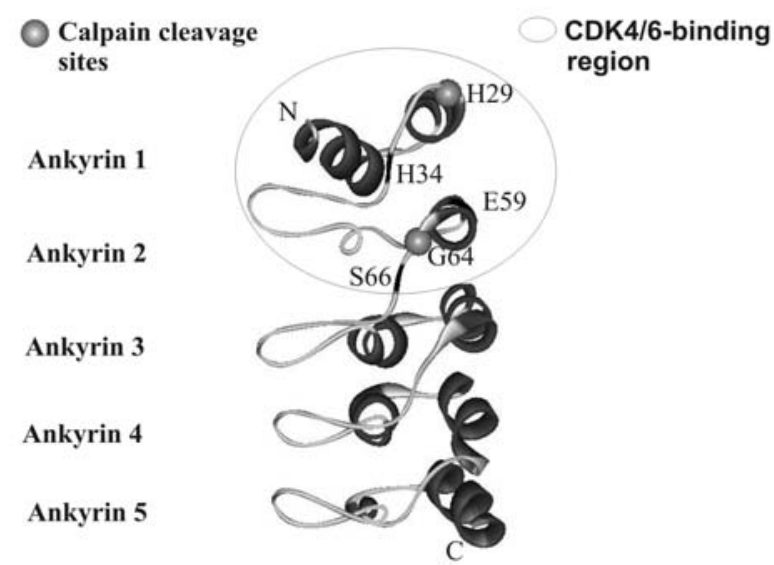

Figure 3 Representation of calpain cleavage sites in p19 and the tertiary structure of p19.

(A) Schematic representation of domain organization and calpain cleavage sites of p19. Peptides generated from p19 in the calpain cleavage reaction were analyzed by $\mathrm{N}$-terminal amino acid sequencing. Downward and upward arrows indicate major and minor calpain cleavage sites, respectively. Major fragments generated by calpain are schematically represented below the full-length sequence of p19. (B) Ribbon diagram schematically depicting p19 tertiary structure and its binding region to CDK4/CDK6. p19 consists of $10 \alpha$-helices assembled sequentially as five ankyrin repeats, forming an elongated structure. Ankyrin repeats 1 and 2 bind to CDK4/CDK6, represented by a circle. The calpain cleavage sites of $p 19$ are denoted with gray spheres. Flexible amino acid residues detected by NMR relaxation studies (H34, E59 and S66) are labeled and the regions corresponding to the respective amino acid residues are marked in black.

\section{Identification of the major calpain cleavage sites in p19 by Edman degradation}

Characterization of the cleavage sites in p19ink4d was accomplished by subjecting proteolytic products to $\mathrm{NH}_{2}^{-}$ sequencing by Edman degradation. The amino acid sequences obtained for p19ink4d were: $R_{26}$ LLHRELV, $\mathrm{R}_{30}$ ELVHPDA, $\mathrm{V}_{48}$ MMFGST, $\mathrm{A}_{65}$ SPNVQDT, $\mathrm{A}_{114}$ VQEGHTA, and $A_{128} E S D L H R R$. The results of the fragments generated from polyvinylidene fluoride (PVDF) analysis and reverse-phase HPLC were mapped on p19ink4d. From these sequences, the calpain cleavage sites in p19ink4d were identified and are schematically shown in Figure $3 \mathrm{~A}$. Fragments containing $R_{30}$ ELVHPDA and $A_{65}$ SPNVQDT as $\mathrm{N}$-terminal amino acid sequences were obtained in detectable amounts from reverse-phase HPLC, and hence we have concluded that the two cleavage sites located between histidine 29 and arginine 30, and between glycine 64 and alanine 65 represent major calpain cleavage sites. The remaining four fragments were obtained in low quantities and thus probably correspond to minor cleavage sites. Figure 3B shows the positions of the major calpain cleavage sites in the three-dimensional structure of $\mathrm{p} 19$.

The RMSD values for each residue from the 20 NMR structures of p19 (PDB ID 1AP7) were calculated and are shown in Figure 4. It is clearly evident from the RMSD plot that the residues after the first and second ankyrin repeats (His29/Arg30 and Gly64/Ala65, respectively) show higher RMSD than the preceding residues.

\section{Discussion}

Transition from the $G_{1}$ to the $S$ phase of the mammalian cell cycle is regulated by the $\mathrm{Rb} / \mathrm{E} 2 \mathrm{~F}$ pathway (Weinberg, 1995). Cyclin D/cyclin-dependent kinase-4/6 complexes phosphorylate the retinoblastoma protein $(p R b)$, which frees E2F from the Rb/E2F complex. The freed E2F activates the transcription of genes involved in cell proliferation (Weinberg, 1995; Leone et al., 1998), and p53-dependent (De Gregore et al., 1997; Bates et al., 


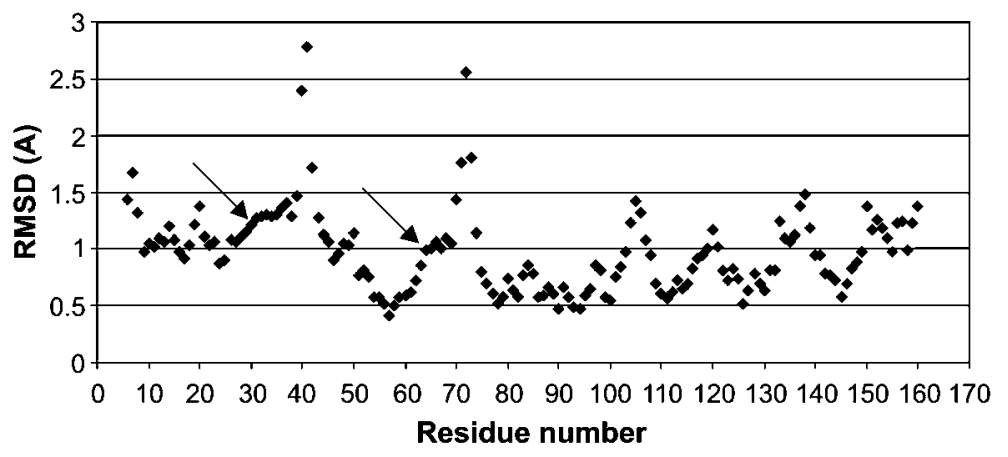

Figure 4 Atomic RMS deviation $(\AA)$ of the backbone atoms of $\mathrm{p} 19$.

A total of 20 NMR structures (PDB ID 1AP7) were used to calculate the RMSD with respect to the mean. The major calpain cleavage sites His29 $\downarrow$ Arg30 and Gly64 $\downarrow$ Ala65 are marked with arrows. Note that these residues show higher RMSD than the preceding residues.

1998) and p53-independent apoptosis (Irwin et al., 2000). INK4 inhibitors specifically inhibit the $\mathrm{G}_{1}$ cyclin-dependent kinase-mediated phosphorylation of $\mathrm{pRb}$, and thus the normal function of the Rb/E2F pathway is deregulated. INK4 inhibitors exert their action by binding directly to CDK4/6 through their two N-terminal ankyrin repeats (Brotherton et al., 1998; Russo et al., 1998). It is interesting to note that the major calpain cleavage sites in p19ink4d are located exactly in these two ankyrin repeats. Calpains should therefore influence p19ink4d inhibitor binding to CDK4/6 and thus may take part in the regulation of this binding in vivo. This proposition is further supported by the observation that CDK6 is resistant to calpain proteolysis. We treated CDK6 with $\mu$-caplain and observed that calpain does not affect CDK6. In addition, we performed cleavage studies on the CDK6/p19 complex. Calpain did not cleave p19 when complexed to CDK6 (data not shown). This is because the major cleavage sites on p19 described above are not accessible to calpain in the CDK6-bound p19. CDK4 and CDK6 have a typical overall bilobal fold found in many eukaryotic protein kinases, with the smaller $\mathrm{N}$-terminal domain consisting predominantly of $\beta$-sheet structure and the larger C-terminal domain consisting primarily of $\alpha$-helices (Pavletich, 1999; Cheek et al., 2002). The structure is globular, in contrast to the elongated rod-like structure of p19ink4d. Resistance of CDK6 and CDK6/p19 to calpain proteolysis, as compared to the propensity of $\mathrm{p} 19^{\text {INK } 4 \mathrm{~d}}$ and cyclin D1 (Choi et al., 1997) for calpain degradation, suggests that calpain may be involved in the cell cycle by regulating the cell cycle regulatory protein turnover. p19 ${ }^{\text {INK } 4 \mathrm{~d}}$ may therefore be a substrate for calpains in these in vivo situations.

There are a limited number of reports on substrate specificity of calpains and these have been reviewed by Croall and Demartino (1991), and more recently by Goll et al. (2003). Early studies suggested that calpains preferentially cleave peptide bonds with a Leu or a Val residue in the P2 position. More complete data, however, indicated that substrate specificity of the calpains is controlled by the conformation of a polypeptide chain and not by an amino acid sequence (Harris et al., 1988; Stabach et al., 1997; Ghosh et al., 2005). In general, the literature data indicate that the calpains cleave target proteins at a limited number of sites and produce large polypeptide fragments rather than small peptides or amino acids (Sasaki et al., 1984; Croall and Demartino, 1991; Goll et al., 2003). A typical example is provided by the $\mathrm{m}$-calpain proteolysis of vimentin. Vimentin belongs to the intermediate filament (IF) family of proteins (Strelkov et al., 2002). All IF proteins share a common structural organization of the dimer that includes a central coiledcoil 'rod' domain flanked by 'head' and 'tail' domains at both ends (Fuchs and Weber, 1994; Strelkov et al., 2002). The $\alpha$-helical core part is not continuous, however, but interrupted in several places, resulting in four consecutive $\alpha$-helical segments that are connected by linkers. The major calpain proteolytic fragments in vimentin arise from cleavage in the unordered amino-terminal headpiece and the tail domain, followed by cleavage in the linker that separates two major coiled-coil domains (Fischer et al., 1986). Another example, related to our $\alpha-$ helical $\mathrm{p} 19$, is provided by $\alpha$-tropomyosin, a polypeptide that is $100 \% \alpha$-helical. Nine of the 11 calpain cleavages in the $\alpha$-tropomyosin polypeptide are in the $\mathrm{COOH}$-terminal half of the molecule (Croall and Demartino, 1991). The $\mathrm{COOH}$-terminal half of the helix is significantly less stable than the $\mathrm{NH}_{2}$-terminal half, again suggesting that the substrate specificity of the calpains depends on the conformation of the polypeptide, with a more open structure favoring cleavage.

The p19 calpain cleavage seems to show yet more features. The major calpain cleavage sites are located at the end of the second helix $(\alpha-2)$ of the first ankyrin repeat (His 29) and again at the end of the second helix $(\alpha-4)$ of the second ankyrin repeat (Gly 64), as evident from Figure 3B. It is clearly apparent from the RMSD plot (Figure 4) that the residues after the first and second ankyrin repeats (His29/Arg30 and Gly64/Ala65, respectively) show higher RMSD than the preceding residues, indicating higher variability and probable flexibility. Our previous relaxation measurements (Renner et al., 1998) on p19 agree with these results. The relaxation measurements and the RMSD values clearly indicate that the first two ankyrin repeats exhibit increased instability. The deformed second ankyrin repeat is dynamically most heterogeneous. It exhibits high flexibility around Val69 on fast time scales. The loop between the first and the second ankyrin repeats shows strong exchange broadening for many residues (His34, Gly42, Thr44, Gln47). Thus, it 
is not surprising that the two major cleavage sites are present around these residues.

In conclusion, our data show new characteristics of calpain action, in that calpains cleaved p19 immediately following the stable $\alpha$-helical segments of the first and second ankyrin repeats that are less stable compared to the other repeats.

\section{Materials and methods}

\section{Chemicals, plasmid, expression host strain and growth media}

BL21 (DE3), DH5- $\alpha$ competent cells and pET-15 vector were purchased from Novagen (Darmstadt, Germany). Luria broth, agar, ampicillin, thrombin, urea were obtained from Sigma (Taufkirchen, Germany). PVDF and nitrocellulose membranes were bought from Amersham Pharmacia Biotech (Freiburg, Germany). The restriction enzymes Nde1, BamH1 and T4 DNA ligase were purchased from New England Biolabs (Beverly, MA, USA). Plasmid miniprep kit and Ni-NTA resin were purchased from Qiagen (Hilden, Germany). p19 anti-rabbit antibody and isopropyl $\beta$-Dthiogalactoside were obtained from Santa Cruz Biotechnology (Santa Cruz, USA) and PeqLabs (Erlangen, Germany), respectively. All other chemicals used were of analytical grade.

\section{Proteolytic cleavage of $\mathrm{p} 19$ by $\mu$-calpain}

Human p19 was expressed and purified in BL21 (DE 3) as a Histag fusion protein (Kalus et al., 1997) using pET15b as an expression vector. The His-tag was removed using $5 \mathrm{U}$ of thrombin per mg of protein. CDK6 was expressed as a GST fusion protein in Spodoptera frugiperda strain Sf9 and purified as previously described (Smialowski et al., 2005). The CDK6/p19 complex (1:3) was purified on a HiLoad 26/60 Superdex 75 preparative grade column using an AKTA explorer gel filtration chromatographic system. Proteolytic cleavage studies were carried out at $25^{\circ} \mathrm{C}$ in $20 \mu \mathrm{l}$ of reaction mixture containing $\mu$-calpain purified from human erythrocytes (Gabrijelcic-Geiger et al., 2001) and p19 at a molar ratio of 1:50, and a calpain assay buffer (25 mM Tris- $\mathrm{HCl}, \mathrm{pH} 7.3,150 \mathrm{~mm} \mathrm{NaCl}, 1 \mathrm{~mm} \mathrm{CaCl}$ ). A similar proteolytic assay was conducted on CDK6/p19 complex. After 1-h incubation, the reactions were terminated by addition of $10 \mathrm{~mm}$ EDTA. The fragments were then separated by SDS-PAGE and visualized by Coomassie brilliant blue staining.

\section{Calpain-mediated proteolytic assays of p19 in the presence or absence of calcium and calpastatin}

The inhibitory role of calpastatin on calpainolytic digestion, the calcium requirement for calpain-mediated proteolysis of $\mathrm{p} 19$, and the stability of $p 19$ in the calpain assay buffer were investigated by performing three separate proteolytic cleavage assays: (1) $\mu$-calpain, p19 and calpastatin domain 1 were incubated in the calpain assay buffer $(25 \mathrm{~mm}$ Tris- $\mathrm{HCl}, \mathrm{pH} 7.3$, $150 \mathrm{~mm} \mathrm{NaCl}, 1 \mathrm{~mm} \mathrm{CaCl}$ ) at a molar ratio of $1: 50: 1$; (2) p19 was incubated with $\mu$-calpain in the calpain assay buffer $(25 \mathrm{~mm}$ Tris- $\mathrm{HCl}, \mathrm{pH} 7.3,150 \mathrm{~mm} \mathrm{NaCl}$ ) at a molar ratio of 50:1; and (3) p19 was digested with $\mu$-calpain in the absence of calpastatin and presence of 1 and $5 \mathrm{mM} \mathrm{CaCl}_{2}$. All reactions were carried out for $1 \mathrm{~h}$ at $25^{\circ} \mathrm{C}$ and then stopped by addition of $10 \mathrm{~mm}$ EDTA.

Calpain-treated samples were resolved by SDS-PAGE and then transferred onto a nitrocellulose membrane with the aid of a semi-dry electroblotting apparatus. Protein transfer from the gel onto the nitrocellulose membrane was carried out at constant power supply of $125 \mathrm{mV}$ for $1 \mathrm{~h}$. The membrane was ini- tially incubated with primary antibodies and then with alkaline phosphatase-conjugated secondary antibodies. It was further washed with Tris buffer and developed by incubation with BCIP/ NBT alkaline phosphatase substrate for 15-30 min.

\section{$\mathrm{N}$-Terminal amino acid analysis of fragments generated by calpain}

Proteolytic reaction mixtures were resolved by SDS-PAGE and then transferred onto a PVDF membrane using a semi-dry electroblotting apparatus with a constant power supply of $125 \mathrm{mV}$ for $1 \mathrm{~h}$. The protein-blotted PVDF membrane was stained with Coomassie brilliant blue. Coomassie-stained bands were cut out from the membrane and then used for $\mathrm{N}$-terminal amino acid analysis by Edman degradation. Sequences obtained were used to map calpain cleavage sites and fragments generated from p19 by calpain-mediated proteolysis.

\section{Acknowledgments}

We thank Isabel Winkelmann and Lourdes García-Ruíz for excellent technical assistance. This work was supported by DFG grant (SFB 469).

\section{References}

Arora, A.S., DeGroen, P.C., Croall, D.E., Emori, Y., and Gores, G.J. (1996). Hepatocellular carcinoma cells resist necrosis during anoxia by preventing phospholipase-mediated calpain activation. J. Cell. Physiol. 167, 434-442.

Bates, S., Phillips, A.C., Clark, P.A., Stott, F., Peters, G., Ludwig, R.L., and Vousden, K.H. (1998). p14(ARF) links the tumour suppressors RB and p53. Nature 395, 124-125.

Bartek, J., Bartkova, J., and Lukas, J. (1997). The retinoblastoma protein pathway in cell cycle control and cancer. Exp. Cell Res. 237, 1-6.

Baumgartner, R., Fernandez-Catalan, C., Winoto, A., Huber, R., Engh, R.A., and Holak, T.A. (1998). Structure of human cyclin-dependent kinase inhibitor p19 (INK4d): comparison to known ankyrin-repeat-containing structures and implications for the dysfunction of tumor suppressor p16 (INK4a). Structure 6, 1279-1290.

Brotherton, D.H., Dhanaraj, V., Wick, S., Brizuela, L., Domaille, P.J., Volyanik, E., Xu, X., Parisini, E., Smith, B.O., Archer, S.J., et al. (1998). Crystal structure of the complex of the cyclin D dependent kinase Cdk6 bound to the cell-cycle inhibitor p19 (INK4d). Nature 395, 244-250.

Cheek, S., Zhang, H., and Grishin, N.V. (2002). Sequence and structure classification of kinases. J. Mol. Biol. 320, 855-881.

Choi, Y.H., Lee, S.J., Nguyen, P., Jang, J.S., Lee, J., Wu, M.L., Takano, E., Maki, M., Henkart, P.A., and Trepel, J.B. (1997). Regulation of cyclin D1 by calpain protease. J. Biol. Chem. 272, 28479-28484.

Croall, D.E. and Demartino, G.N. (1991). Calcium-activated neutral protease (calpain) system - structure, function, and regulation. Physiol. Rev. 71, 813-847.

Dayton, W.R., Schollmeyer, J.V., Lepley, R.A., and Cortes, L.R. (1981). A calcium-activated protease possibly involved in myofibrillar protein-turnover-isolation of a low-calcium-requiring form of the protease. Biochim. Biophys. Acta 659, 48-61.

De Gregore, J., Leone, G., Miron, A., Jakoi, L., and Nevins, J.R. (1997). Distinct roles for E2F proteins in cell growth control and apoptosis. Proc. Natl. Acad. Sci. USA 94, 7245-7250.

Du, X.P., Saido, T.C., Tsubuki, S., Indig, F.E., Williams, M.J., and Ginsberg, M.H. (1995). Calpain cleavage of the cytoplasmic domain of the integrin $\beta 3$ subunit. J. Biol. Chem. 270, 26146-26151. 
Fischer, S., Vandekerckhove, J., Ampe, C., Traub, P., and Weber, K. (1986). Protein-chemical identification of the major cleavage sites of the $\mathrm{Ca}^{2+}$ proteinase on murine vimentin, the mesenchymal intermediate filament protein. Biol. Chem. Hoppe-Seyler 367, 1147-1152.

Fuchs, E. and Weber, K. (1994). Intermediate filaments - structure, dynamics, function, and disease. Annu. Rev. Biochem. 63, 345-382.

Gabrijelcic-Geiger, D., Mentele, R., Meisel, B., Hinz, H., AssfalgMachleidt, L., Machleidt, W., Moller, A., and Auerswald, E.A. (2001). Human $\mu$-calpain: simple isolation from erythrocytes and characterization of autolysis fragments. Biol. Chem. 382, 1733-1737.

Ghosh, M., Shanker, S., Siwanowicz, I., Mann, K., Machleidt, W., and Holak, T.A. (2005). Proteolysis of insulin-like growth factor binding proteins (IGFBPs) by calpain. Biol. Chem. 386, 85-93.

Glading, A., Lauffenburger, D.A., and Wells, A. (2002). Cutting to the chase: calpain proteases in cell motility. Trends Cell Biol. $12,46-54$.

Goll, D.E., Thompson, V.F., Li, H.Q., Wei, W., and Cong, J.Y. (2003). The calpain system. Physiol. Rev. 83, 731-801.

Harper, J.W. and Elledge, S.J. (1996). Cdk inhibitors in development and cancer. Curr. Opin. Genet. Dev. 6, 56-64.

Harris, A.S., Croall, D.E., and Morrow, J.S. (1988). The calmodulin-binding site in $\alpha$-fodrin is near the calcium-dependent protease-I cleavage site. J. Biol. Chem. 263, 15754-15761.

Huang, Y. and Wang, K.K. (2001). The calpain family and human disease. Trends Mol. Med. 7, 355-362.

Inomata, M., Hayashi, M., Nakamura, M., Saito, Y., and Kawashima, S. (1989). Properties of erythrocyte-membrane binding and autolytic activation of calcium-activated neutral protease. J. Biol. Chem. 264, 18838-18843.

Inomata, M., Saito, Y., Kon, K., and Kawashima, S. (1990). Binding-sites for calcium-activated neutral protease on erythrocyte membranes are not membrane phospholipids. Biochem. Biophys. Res. Commun. 171, 625-632.

Irwin, M., Marin, M.C., Phillips, A.C., Seelan, R.S., Smith, D.I., Liu, W.G., Flores, E.R., Tsai, K.Y., Jacks, T., Vousden, K.H., and Kaelin, W.G. (2000). Role for the p53 homologue p73 in E2F-1-induced apoptosis. Nature 407, 645-648.

Kalus, W., Baumgartner, R., and Renner, C., Noegel, A., Chan, F.K.M., Winoto, A., and Holak, T.A. (1997). NMR structural characterization of the CDK inhibitor p19 (INK4d). FEBS Lett. 401, 127-132.

Khorchid, A. and Ikura, M. (2002). How calpain is activated by calcium. Nat. Struct. Biol. 9, 239-241.

Kuboki, M., Ishii, H., and Kazama, M. (1987). Procalpain is activated on the plasma-membrane and the calpain acts on the membrane. Biochim. Biophys. Acta 929, 164-172.

Kuboki, M., Ishii, H., and Kazama, M. (1990). Characterization of calpain-I binding-proteins in human erythrocyte plasmamembrane. J. Biochem. 107, 776-780.

Lee, W.J., Adachi, Y., Maki, M., Hatanaka, M., and Murachi, T. (1990). Factors influencing the binding of calpain-I to human erythrocyte inside-out vesicles. Biochem. Int. 22, 163-171.

Leone, G., DeGregori, J., Yan, Z., Jakoi, L., Ishida, S., Williams, R.S., and Nevins, J.R. (1998). E2F3 activity is regulated during the cell cycle and is required for the induction of $S$ phase. Genes Dev. 12, 2120-2130.

Li, H., Thompson, V.F., and Goll, D.E. (2004). Effects of autolysis and properties of $\mu$-and m-calpain. Biochim. Biophys. Acta 1691, 91-103.

Mellgren, R.L. (1980). Canine cardiac calcium-dependent proteases - resolution of two forms with different requirements for calcium. FEBS Lett. 109, 129-133.

Moldoveanu, T., Hosfield, C.M., Lim, D., Elce, J.S., Jia, Z.C., and Davies, P.L. (2002). A Ca ${ }^{2+}$ switch aligns the active site of calpain. Cell 108, 649-660.

Moldoveanu, T., Hosfield, C.M., Lim, D., Jia, Z., and Davies, P.L. (2003). Calpain silencing by a reversible intrinsic mechanism. Nat. Struct. Biol. 10, 371-378.
Molinari, M., Anagli, J., and Carafoli, E. (1994). $\mathrm{Ca}^{2+}$-activated neutral protease is active in the erythrocyte-membrane in its nonautolyzed $80-\mathrm{kDa}$ form. J. Biol. Chem. 269, 27992-27995.

Morgan, D.O. (1995). Principles of Cdk regulation. Nature 374, 131-134.

Nicotera, P., Hartzell, P., Baldi, C., Svensson, S.A., Bellomo, G., and Orrenius, S. (1986). Cystamine induces toxicity in hepatocytes through the elevation of cytosolic $\mathrm{Ca}^{2+}$ and the stimulation of a nonlysosomal proteolytic system. J. Biol. Chem. 261, 4628-4635.

Pal, G.P., De Veyra, T., Elce, J.S., and Jia, Z.C. (2003). Crystal structure of a $\mu$-like calpain reveals a partially activated conformation with low $\mathrm{Ca}^{2+}$ requirement. Structure 11, 1521-1526.

Patel, Y.M. and Lane, M.D. (2000). Mitotic clonal expansion during preadipocyte differentiation: calpain-mediated turnover of p27. J. Biol. Chem. 275, 17653-17660.

Pavletich, N.P. (1999). Mechanisms of cyclin-dependent kinase regulation: structures of Cdks, their cyclin activators, and Cip and INK4 inhibitors. J. Mol. Biol. 287, 821-828.

Pines, J. (1996). Cell cycle: reaching for a role for the CDKs proteins. Curr. Biol. 6, 1399-1402.

Renner, C., Baumgartner, R., Noegel, A.A., and Holak, T.A. (1998). Backbone dynamics of the CDK inhibitor p19ink4d studied by $\mathrm{N}-15$ NMR relaxation experiments at two field strengths. J. Mol. Biol. 283, 221-229.

Ruas, M. and Peters, G. (1998). The p16 ${ }^{\mathrm{INK} 4 \mathrm{a}} / \mathrm{CDKN} 2 \mathrm{~A}$ tumor suppressor and its relatives. Biochim. Biophys. Acta 1378, 115-177.

Russo, A.A., Tong, L., Lee, J.O., Jeffrey, P.D., and Pavletich, N.P. (1998). Structural basis for inhibition of the cyclin-dependent kinase Cdk6 by the tumour suppressor p16 ${ }^{\text {INk4a }}$. Nature 395, 237-243.

Sasaki, T., Kikuchi, T., Yumoto, N., Yoshimura, N., and Murachi, T. (1984). Comparative specificity and kinetic-studies on porcine calpain-I and calpain-li with naturally-occurring peptides and synthetic fluorogenic substrates. J. Biol. Chem. 259, 2489-2494.

Serrano, M. (1997). The tumor suppressor protein p161NK4a. Exp. Cell Res. 237, 7-13.

Serrano, M., Lin, A.W., McCurrach, M.E., Beach, D., and Lowe, S.W. (1997). Oncogenic ras provokes premature cell senescence associated with accumulation of p53 and p16 $16^{\text {INk4a }}$. Cell 88, 593-602.

Sherr, C.J. and Roberts, J.M. 1999. CDK inhibitors: positive and negative regulators of $\mathrm{G}_{1}$-phase progression. Genes Dev. 13 , 1501-1512.

Smialowski, P., Singh, M., Mikolajka, A., Majumdar, S., Joy, J.K., Nalabothula, N., Krajewski, M., Degenkolbe, R., Bernard, H.U., and Holak, T.A (2005). NMR and mass spectrometry studies of putative interactions of cell cycle proteins $\mathrm{pRb}$ and CDK6 with cell differentiation proteins MyoD and ID-2. Biochim. Biophys. Acta 1750, 48-60.

Spencer, M.J., Croall, D.E., and Tidball, J.G. (1995). Calpains are activated in necrotic fibers from $\mathrm{Mdx}$ dystrophic mice. J. Biol. Chem. 270, 10909-10914.

Stabach, P.R., Cianci, C.D., Glantz, S.B., Zhang, Z.S., and Morrow, J.S. (1997). Site-directed mutagenesis of $\alpha$ ll spectrin at codon 1175 modulates its $\mu$-calpain susceptibility. Biochemistry $36,57-65$.

Strelkov, S.V., Herrmann, H., Geisler, N., Wedig, T., Zimbelmann, R., Aebi, U., and Burkhard, P. (2002). Conserved segments $1 \mathrm{~A}$ and $2 \mathrm{~B}$ of the intermediate filament dimer: their atomic structures and role in filament assembly. EMBO J. 21, 1255-1266.

Tompa, P. and Friedrich, P. (2000). Kinetic analysis of human $\mu$ calpain autolysis. In: Calpain Methods and Protocols, J.S. Elce, ed. (Totowa, NJ, USA: Humana Press), pp. 129-136.

Tsutsumi, M., Tsai, Y.C., Gonzalgo, M.L., Nichols, P.W., and Jones, P.A. (1998). Early acquisition of homozygous deletions of p16/p19 during squamous cell carcinogenesis and genetic mosaicism in bladder cancer. Oncogene 17, 3021-3027. 
Weinberg, R.A. (1995). The retinoblastoma protein and cell-cycle control. Cell 81, 323-330.

Zindy, F., Besten, W., Chen, B., Rehg, J.E., Latres, E., Barbacid, M., Pollard, J.W., Sherr, C.J., Cohen, P.E., and Roussel, M.F. (2001). Control of spermatogenesis in mice by the cyclin D- dependent kinase inhibitors $\mathrm{p} 18^{\operatorname{lnk} 4 \mathrm{c}}$ and $\mathrm{p} 19^{\operatorname{lnk} 4 d}$. Mol. Cell. Biol. 9, 3244-3255.

Received September 19, 2005; accepted November 29, 2005 